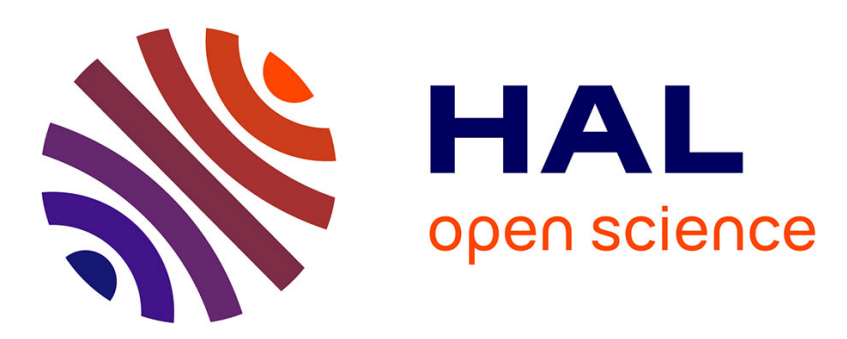

\title{
Resting Tension Participates in the Modulation of Active Tension in Isolated Guinea Pig Ventricular Myocytes
}

Olivier Cazorla, Caroline Pascarel, Didier Garnier, Jean-Yves Le Guennec

\section{To cite this version:}

Olivier Cazorla, Caroline Pascarel, Didier Garnier, Jean-Yves Le Guennec. Resting Tension Participates in the Modulation of Active Tension in Isolated Guinea Pig Ventricular Myocytes. Journal of Molecular and Cellular Cardiology, 1997, 29 (6), pp.1629-1637. 10.1006/jmcc.1997.0402 . hal01824420

\section{HAL Id: hal-01824420 \\ https://hal.umontpellier.fr/hal-01824420}

Submitted on 12 Apr 2020

HAL is a multi-disciplinary open access archive for the deposit and dissemination of scientific research documents, whether they are published or not. The documents may come from teaching and research institutions in France or abroad, or from public or private research centers.
L'archive ouverte pluridisciplinaire HAL, est destinée au dépôt et à la diffusion de documents scientifiques de niveau recherche, publiés ou non, émanant des établissements d'enseignement et de recherche français ou étrangers, des laboratoires publics ou privés. 


\title{
Resting Tension Participates in the Modulation of Active Tension in Isolated Guinea Pig Ventricular Myocytes
}

\author{
Olivier Cazorla, Caroline Pascarel, Didier Garnier and \\ Jean-Yves Le Guennec \\ Laboratoire de Physiologie des Cellules Cardiaques et Vasculaires, CNRS UMR 6542, \\ Faculté des Sciences, 37200 Tours, France
}

\begin{abstract}
O. Cazorla, C. Pascarel, D. Garnier and J.-Y. Le Guennec. Resting Tension Participates in the Modulation of Active Tension in Isolated Guinea Pig Ventricular Myocytes

We studied active and passive properties of intact isolated guinea-pig ventricular myocytes in auxotonic conditions. Cells were attached using carbon fibres. The passive properties of the myocytes, in the presence of the stretch-activated channel blocker streptomycin sulphate, could be separated into two groups: stiff cells (stiffness slope $=2.88 \pm 0.93 \mathrm{nN} / \mu \mathrm{m}^{3}, n=63$ cells) and compliant cells (stiffness slope $=0.91 \pm 0.35 \mathrm{nN} / \mu \mathrm{m}^{3}$, $n=52$ cells). The study and the localization of the different kind of cells indicated that endocardium is mainly constituted of stiff cells $(80 \%)$ while the epicardium contained more compliant cells $(60 \%)$. When a longitudinal strain was applied to compliant cells, an increase in resting tension, diastolic sarcomere length and active tension were observed. On the other hand, in stiff cells, it induced an increase in resting tension and active tension with little change of diastolic sarcomere length. In both kinds of cells, strain had no effect on $\mathrm{Ca}^{2+}$ transient amplitude and shape. Plotting active tension $v$ diastolic sarcomere length also clearly showed two separated populations of cells, corresponding to stiff and compliant cells. The results of the two groups of cells when plotting active tension $v$ resting tension could not be distinguished. We conclude that resting tension is an important factor in the modulation of active tension by stretch in addition to interfilament lattice spacing or sarcomere length.
\end{abstract}

Key WorDs: Cardiac myocytes; Excitation-contraction coupling; Stretch; Frank-Starling law; Length-tension relationship.

\section{Introduction}

Stretching a striated muscle normally results in an increase of the active tension developed during a twitch. It is known that the positive inotropism of stretch, in skeletal muscle, is mainly due to geometrical rearrangements of contractile proteins. Even, if this participates to the cardiac lengthtension curve, it is admitted that the steep positive inotropism of stretch is a consequence of an increase of the $\mathrm{Ca}^{2+}$ sensitivity of the contractile machinery (Hibberd and Jewell, 1982; Babu et al., 1988).
The mechanisms by which stretch modulates the $\mathrm{Ca}^{2+}$ sensitivity of troponin $\mathrm{C}(\mathrm{TnC})$ are not understood. It is established that force developed during cross-bridge interactions may modulate $\mathrm{Ca}^{2+}$ binding to $\mathrm{TnC}$ in rigor bridges (Hofmann and Fuchs, 1987) or during calcium activation (Allen and Kentish, 1988) independently of cell length. With stretch, cell parameters like cell length, cell width and height (and consequently interfilament spacing) and resting tension may change. Some authors have suggested that cell length may modulate active tension through modifications of the

Please address all correspondence to: Jean-Yves Le Guennec, Laboratoire de Physiologie des Cellules Cardiaques et Vasculaires, CNRS UMR 6542, Faculté des Sciences, 37200 Tours, France. 
interfilament spacing (Hibberd and Jewell, 1982; DeBeer et al., 1988). The interfilament spacing varies inversely with cell length because cells have a constant volume, i.e. as the cell length is increased the interfilament spacing decreases. Recent works on skinned muscle cardiac fibres have demonstrated that interfilament spacing could be an important modulator of the force of contraction (McDonald and Moss, 1995; Wang and Fuchs, 1995; Fuchs and Wang, 1996). The idea is that this lattice spacing may have an ideal size below and above which the actomyosin complex would form less efficiently.

In 1994, Gannier et al. showed that streptomycin, a stretch activated channel blocker, could inhibit the large increase in resting calcium induced by stretch of guinea-pig ventricular myocytes. This work revealed two distinct populations of ventricular myocytes which were distinguished by their passive stiffness. In the present study, we confirm the existence of the two populations of cells. We compare the effects of stretch on passive tension, active tension and sarcomere length (SL) on these two kinds of cells. We find that resting tension, in addition to sarcomere length or interfilament spacing per se, is important in the modulation of active tension during a cell stretch.

\section{Materials and Methods}

\section{Cells isolation}

Guinea pigs were killed by cervical dislocation following stunning, and hearts were excised. Ventricular myocytes were enzymatically isolated as previously described (Le Guennec et al., 1990). Following isolation, cells were placed in the experimental chamber of a Nikon diaphot inverted microscope and superfused with a physiological saline solution (PSS) of the following composition (in mM): $140 \mathrm{NaCl}, 5.4 \mathrm{KCl}, 1 \mathrm{MgCl}_{2}, 1.8 \mathrm{CaCl}_{2}$, 11 glucose, $0.33 \quad \mathrm{NaH}_{2} \mathrm{PO}_{4}, 0.04$ streptomycin sulphate, 10 HEPES; pH adjusted to 7.3 with $\mathrm{NaOH}$. Streptomycin sulphate was added to the Tyrode solution to prevent the large increase in resting calcium induced by stretch (White et al., 1993; Gannier et al., 1994, 1996), and thus to unmask the two populations of cells. In some experiments (see Results), cells from the apex, base, endocardium or epicardium of left and right ventricles were obtained by cutting the digested heart with fine scissors.

\section{Measurement of $\left[\mathrm{Ca}^{2+}\right]_{i}$}

Myocytes were loaded with the fluorescent $\mathrm{Ca}^{2+}$ indicator, Indo-1 (AM form, Sigma, France), as described previously (Gannier et al., 1994). The ratio of emitted fluorescence at 405 (F405) and $480 \mathrm{~nm}(\mathrm{~F} 480)$ was used to calculate $\left[\mathrm{Ca}^{2+}\right]_{\mathrm{i}}$ according to the equation:

$$
\left[\mathrm{Ca}^{2+}\right]=\mathrm{K}_{\mathrm{d}} \cdot \beta \cdot\left(\mathrm{R}-\mathrm{R}_{\min }\right) /\left(\mathrm{R}_{\max }-\mathrm{R}\right)
$$

where $R_{\min }$ and $R_{\max }$ are the fluorescence ratios F405/F480 obtained in the absence of $\mathrm{Ca}^{2+}$ and at saturating $\left[\mathrm{Ca}^{2+}\right]$ respectively (see later). $\beta$ is the ratio of the $480 \mathrm{~nm}$ signal in the absence and at saturating $\left[\mathrm{Ca}^{2+}\right]$. A value of $380 \mathrm{~nm}$ was assumed for the $\mathrm{K}_{\mathrm{d}}$ (the dissociation constant) at the temperature at which experiments were performed $\left(26-27^{\circ} \mathrm{C}\right.$; Bers et al., 1989). The calibration of Indo-1 was performed in cells as already described by Gannier et al. (1994). Due to uncertainties inherent in the calibration procedure of the AM form of the dye (O'Neill et al., 1990), two scales (ratio and concentration) were always given.

A shutter (UniBlitz D122 shutter driver, USA) was placed between the Xenon lamp and the objective of the microscope. The shutter was opened for $1.5 \mathrm{~s}$ every $4 \mathrm{~s}$ in order to reduce photobleaching of the $\mathrm{Ca}^{2+}$-indicator. Cells were field stimulated by platinum electrodes every $4 \mathrm{~s}$ (White et al., 1993).

\section{Stretching cells and the measurement of sarcomere length}

In order to attach and stretch cardiac cells, we used carbon fibres (Le Guennec et al., 1990; White et al., 1995). We attached these fibres close to the ends, and perpendicular to the long axis of the cells. A stiff fibre, with a compliance of $0.3 \mu \mathrm{m} / \mu \mathrm{N}$ was attached to one end of the cell and a more supple fibre with a compliance of approximately $50 \mu \mathrm{m} /$ $\mu \mathrm{N}$ was attached to the other end of the cell. After attachment, the cell under study was lifted to avoid friction between the cell and the coverglass. The compliance of each carbon fibre was determined using a force transducer (Ackers AE801) (Le Guennec et al., 1990). During a twitch, the supple fibre moved and active tension was calculated from the displacement. For each cell, we first measured the maximum shortening during a twitch under isotonic conditions to be sure that, after attachment to carbon fibres, auxotonic contractions are not limited by restoring forces (see White et al., 1995). Cells were stretched by manually displacing the stiff fibre along the longitudinal axis of the cell. Stretch 
induced changes in cell and SL of varying importance depending on the stiffness of the individual cell. For each cell, we measured its width. Force was normalized to the cross-section area assuming a cell height of $16 \mu \mathrm{m}$ (Le Guennec et al., 1990) since it is a quite conserved value (see Fabiato, 1981). When we compared the width of the different cells groups, we did not find any differences. This allows us to make the assumption that the morphology of the cross section of the cells is the same in the different groups. Cells were positioned with a remotely controlled rotatable experimental chamber (Kohl et al., 1994). Sarcomere length was determined along the cell by using a fast Fourier transform algorithm on an acquired video image of the cell (Gannier et al., 1993). The sampling frequency of video image acquisition $(50 \mathrm{~Hz})$ is fast enough to have a precise idea of the peak tension during a twitch. Resting tension was determined, assuming no tension at slack sarcomere length.

\section{Statistical analysis}

To compare mean results obtained from the two populations of cells, the non-parametric MannWhitney U test and unpaired Student $t$-test were used (both tests gave the same results). For correlation, we used the Bravais Pearson test. For all tests, the level of significance was set at $1 \%$. Results are expressed as mean \pm standard deviation $(n=$ number of cells studied).

\section{Results}

Description of two groups of cells on the basis of their passive properties

A first batch of 43 cells was used to study the effects of stretch on passive and active tension. Then the passive properties of a second batch of 84 cells were studied to detect any localization of the two kind of cells (see below). For each cell, we measured the SL at slack length and after stretching to different lengths. Resting tension was also measured in these conditions assuming no resting tension at slack length. The results are shown in Figure 1 and revealed that two kinds of cells can be observed: (1) cells in which stretch induced cell and sarcomere lengthening was associated with an increase in resting tension. These cells are termed compliant cells; (2) cells in which stretch induced a large increase in resting tension associated with less cell

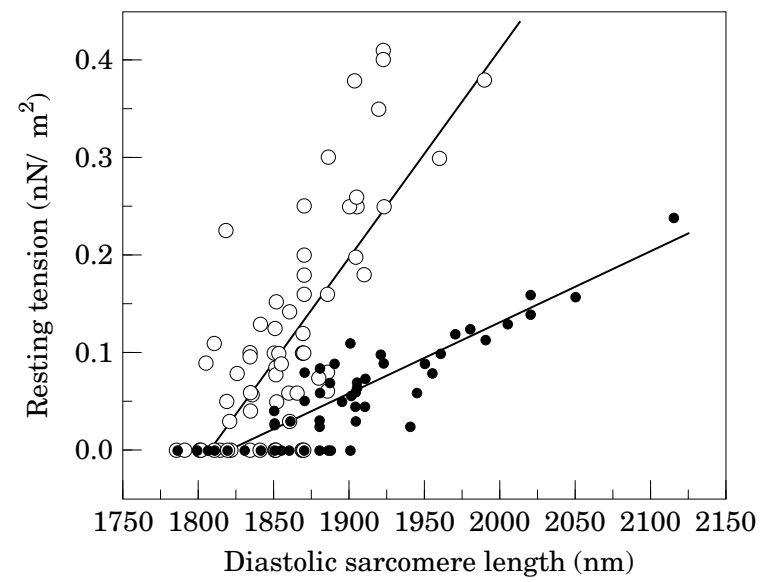

Figure 1 Distinction of different populations of cells based upon their passive stiffness. Resting tension is plotted $v$ sarcomere length after different stretches for all studied cells $(n=43)$. Compliant cells (closed circles, $n=$ 22) are distinguishable in this representation from stiff cells (open circles, $n=21$ ) by the slope of the lengthtension curve. Two significant correlations were found with slopes of $2.3 \pm 0.2$ and $0.74 \pm 0.05 \mathrm{nN} / \mu \mathrm{m}^{3}$ for stiff and compliant cells, respectively. Lines represent the linear regression for each group of cells. Correlation coefficients are 0.82 and 0.87 for stiff and compliant cells, respectively.

and sarcomere lengthening. We term these cells stiff or rigid cells. A stiffness slope of $1.7 \mathrm{nN} / \mu \mathrm{m}^{3}$ was set as the threshold between stiff and compliant cells (Gannier et al., 1994). There were 21 stiff cells and 22 compliant cells obtained from the whole ventricles. As reported by Gannier et al. (1994), the resting calcium and, above all, the slack SL $(17 \pm 19 \mathrm{nM}, \quad 1830 \pm 30 \mathrm{~nm}$ and $24 \pm 47 \mathrm{~nm}$, $1850 \pm 40 \mathrm{~nm}$ for stiff and compliant cells, respectively) were not significantly different in the two cell groups, excluding a high stiffness resulting from calcium overload of some cells. Also, the calcium transients evoked by field stimulation of the cells were not different in the two cell groups: the calcium transient amplitude $(227 \pm 67 \mathrm{~nm}$ and $194 \pm 59 \mathrm{~nm}$ for stiff and compliant cells, respectively) and shape (calcium transient duration measured at $50 \%$ relaxation $780 \pm 240 \mathrm{~ms}$ and $775 \pm 168 \mathrm{~ms}$ for stiff and compliant cells, respectively) were not significantly different. Moreover, these transients were insensitive to stretch in the two cell populations (Fig. 2) as already described (White et al., 1995). It is worth noting that both kinds of cells were found for the same cell isolation. We never observed just one kind of cell per isolation procedure. To test if there is a spatial localization of the different kind of cells in the heart, we measured the resting tension, at different lengths, of cells obtained from the left or right ventricle, from the 

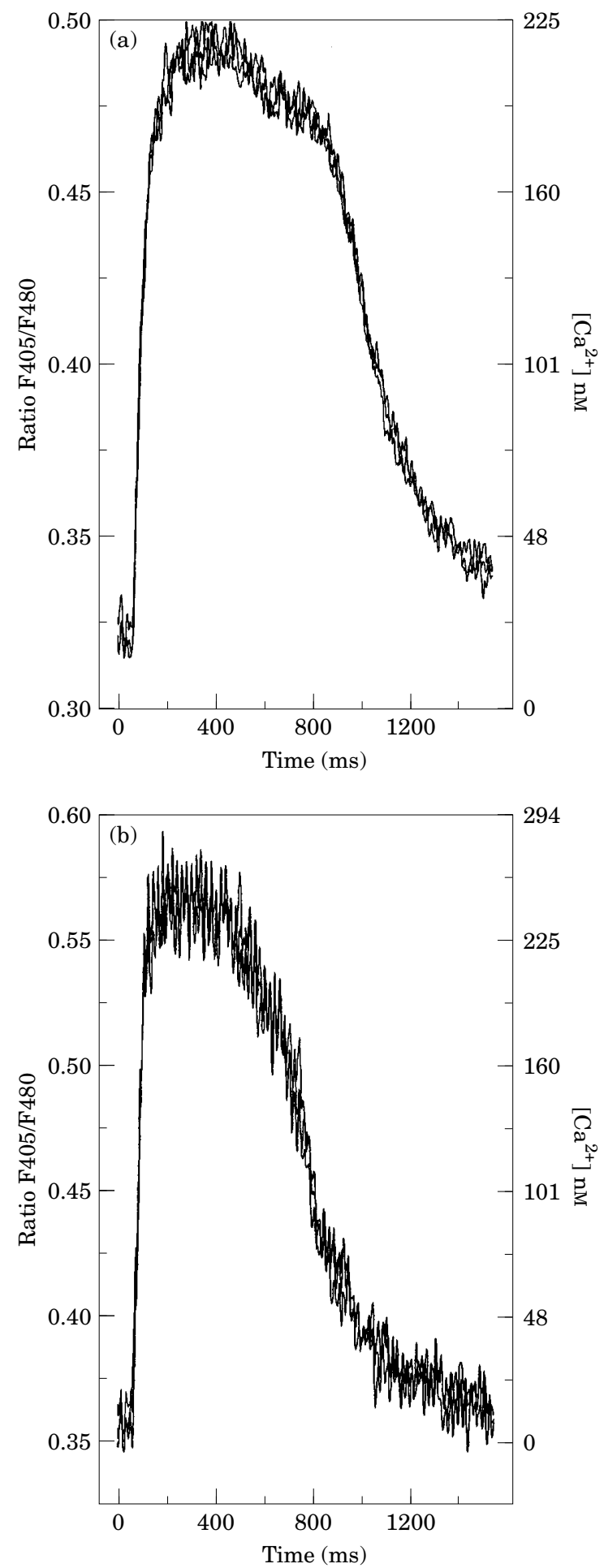

Figure 2 Calcium transients evoked by field stimulation at $0.25 \mathrm{~Hz}$, obtained from a compliant cell (a) and a stiff cell (b). The transients were obtained at slack length and after two stretches inducing an increase of active tension of 135 and $172 \%$ for the stiff cell and of 150 and $176 \%$ in compliant cell. In both cases, there was no obvious modification of the calcium transient which almost perfectly superimpose in this figure.
Table 1 Repartition of compliant and stiff cells in different parts of the heart. The percentage of cells, classified as compliant and stiff, found in the part of the heart given in the first column is given in the second and third columns, respectively. Bracketed numbers are numbers of cells found in the given category out of the total of studied cells. A stiffness slope of $1.7 \mathrm{nN} / \mu \mathrm{m}^{3}$ was determined to distinguish both kind of cells. The cells given in this table do not include the 43 cells of the rest of the study

\begin{tabular}{llc}
\hline & \multicolumn{1}{c}{ Compliant } & Stiff \\
\hline Left & $40 \%(17 / 42)$ & $60 \%(25 / 42)$ \\
Right & $40 \%(17 / 43)$ & $60 \%(26 / 43)$ \\
Apex & $44 \%(8 / 18)$ & $56 \%(10 / 18)$ \\
Base & $33 \%(9 / 27)$ & $67 \%(18 / 27)$ \\
Endocardial & $20 \%(3 / 16)$ & $80 \%(13 / 16)$ \\
Epicardial & $60 \%(14 / 24)$ & $40 \%(10 / 24)$ \\
\hline
\end{tabular}

apex or base of the ventricles, from the endocardium or epicardium of both ventricles. The results are summarized in Table 1. It is clear on this table that there is a tendency for stiff cells to be localized in the endocardium and for compliant cells in the epicardium (see Discussion).

Active properties of the two groups of cells with stretch

Stretching compliant cells resulted in an increase of resting tension, diastolic SL and active tension (Fig. 3). Care was taken to avoid restoring forces since cell contractions were in auxotonic conditions. For stiff cells, the behaviour was quite different, since, although a stretch induced an increase in resting tension and active tension, it was not associated with a measurable increase in diastolic SL (Fig. 4). Care was taken to ensure that cells were not attached to the coverglass so that our observations were not the consequence of lifting the cell from the bottom of the chamber. Thus, it is clear that stretch may induce a positive inotropism without any change in SL.

In order to determine if there are any factors in common in the modulation of active force by stretch for the two groups of cells, we correlated active tension with different parameters. For each cell, we plotted active tension $v$ diastolic SL [Fig. 5(a)]. If we correlate pooled data from stiff and compliant cells, a non-significant correlation is obtained $(r=$ 0.37 ). Correlating active tension and diastolic sarcomere length only gave significant results when the data were separated into stiff and compliant cells. The same results were obtained when plotting active tension $v$ sarcomere shortening (not shown) 

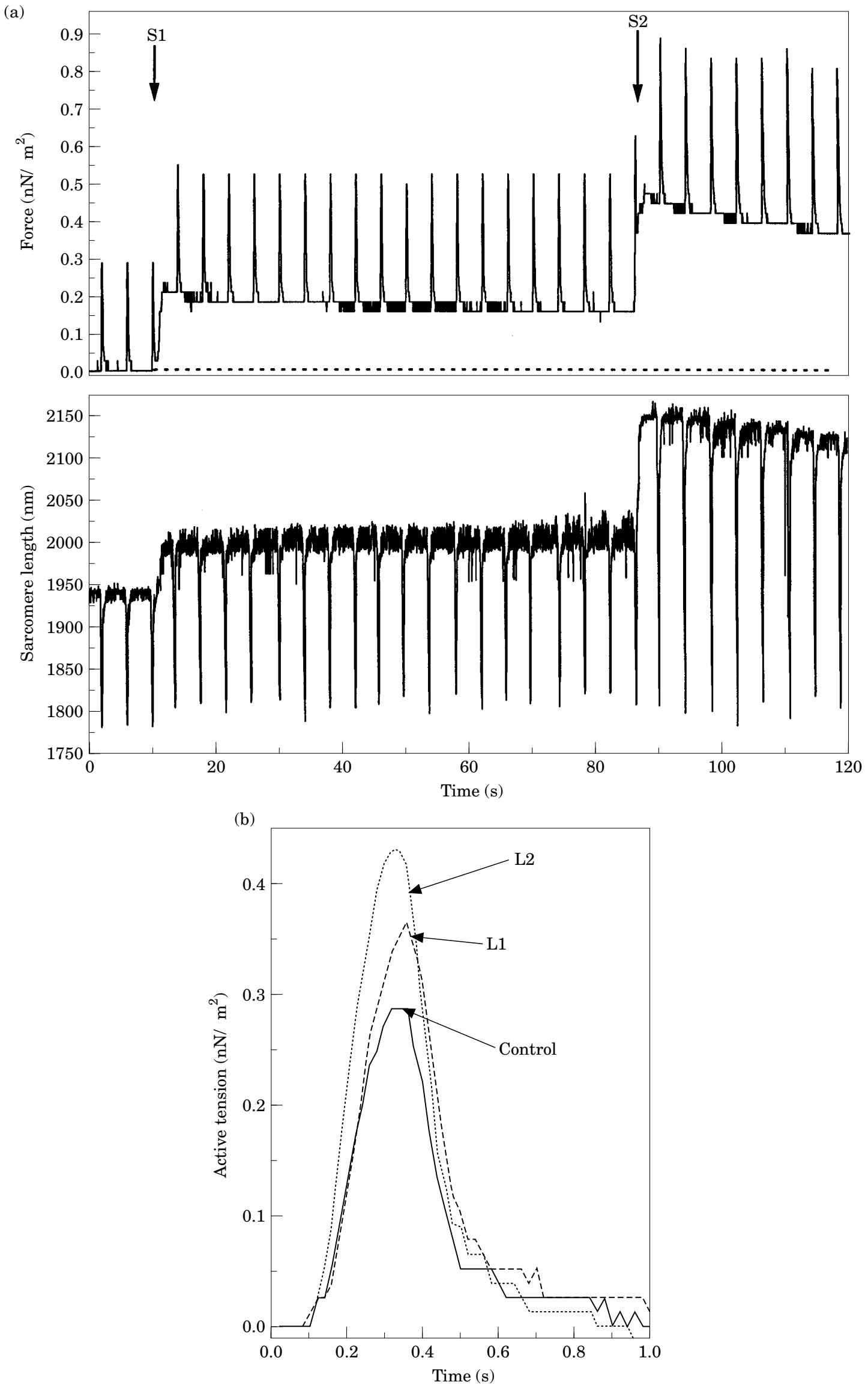

Figure 3 Contractile properties of a compliant cell at different levels of stretch. (a) Evolution of tension (upper trace) and of sarcomere length (lower trace) before and after two stretches (S1 and S2). The cell was electrically stimulated at $0.25 \mathrm{~Hz}$. (b) Examples of individual contractions after subtraction of the resting tension on an expanded time scale before and after the two stretches (L1 and L2). 

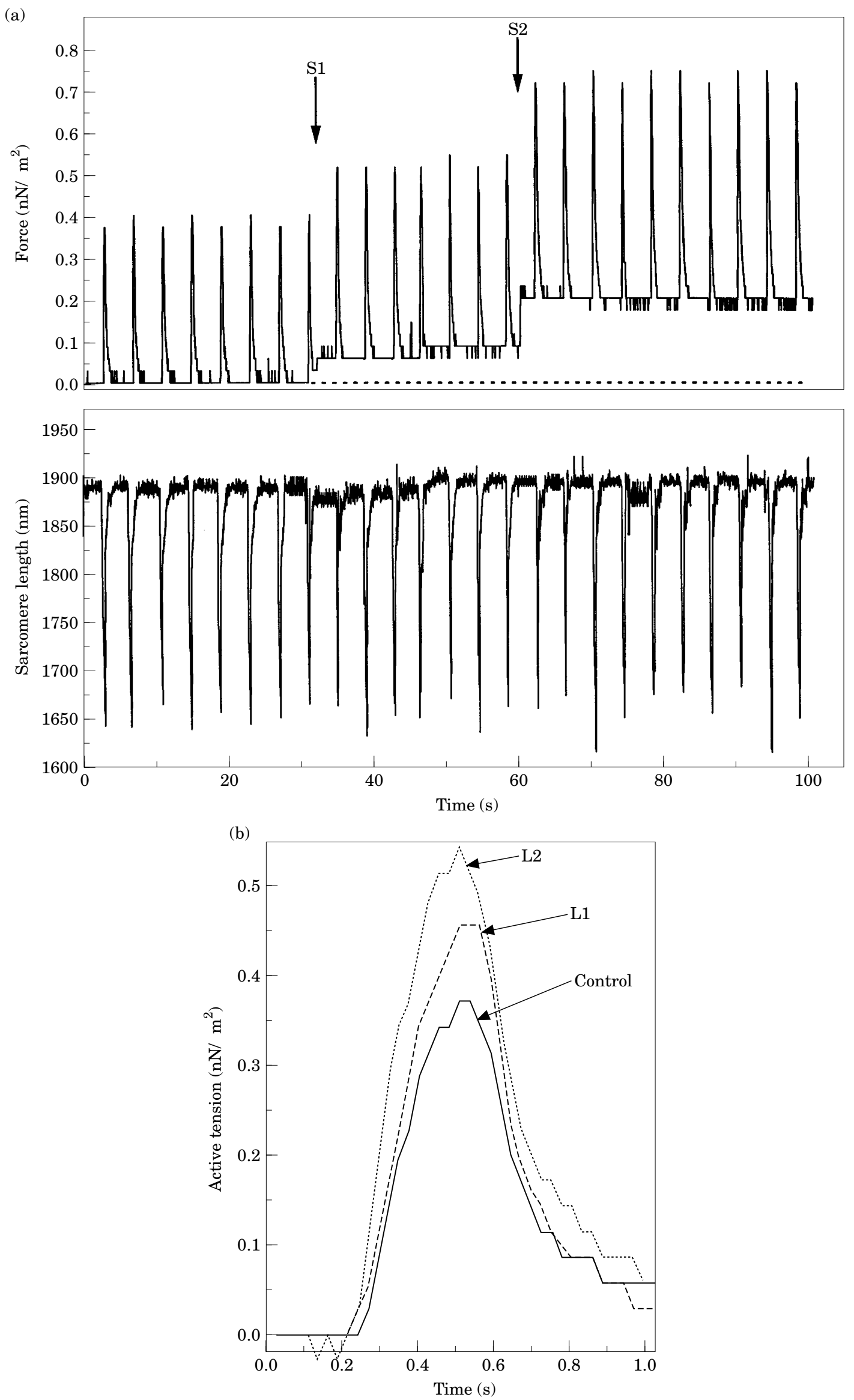

Figure 4 Contractile properties of a stiff cell at different levels of stretch. Labels and experimental protocol have the same meaning as in Figure 3. 

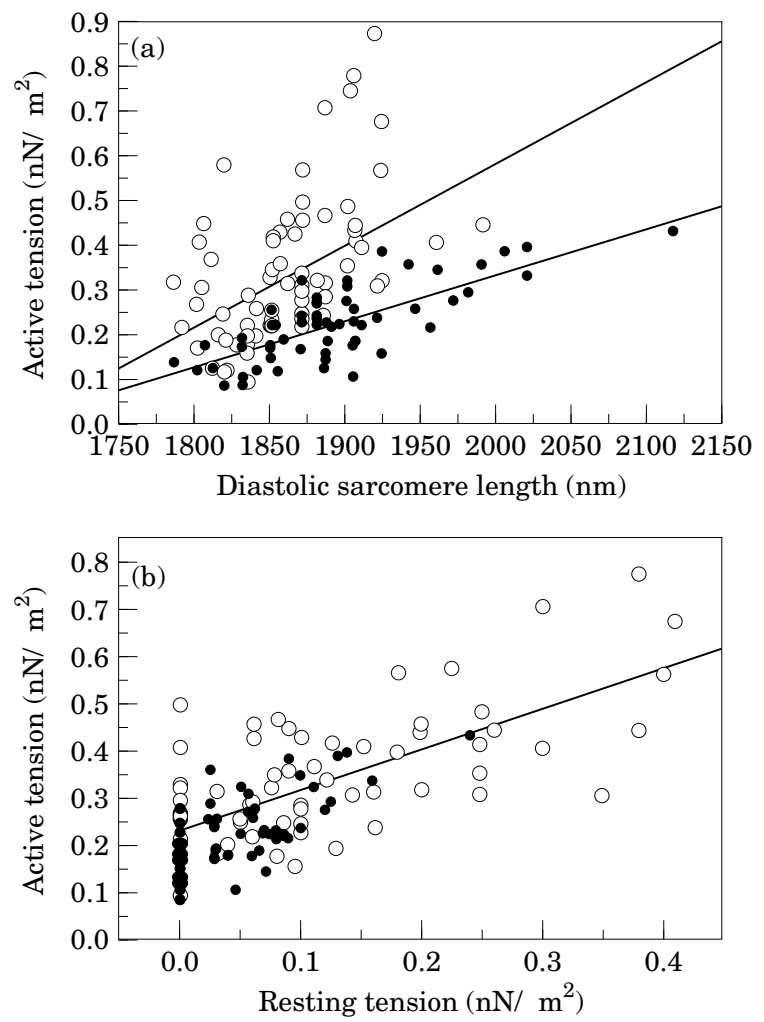

Figure 5 Effects of stretch on the active tension of stiff and compliant cells. (a) Plot of active tension $v$ diastolic sarcomere length (SL). The stiff cells (open circles) develop an active tension superior to that of compliant cells (closed circles) for a similar diastolic SL. Correlating SL and active tension for the total data was not significant, while significant correlations for SL and active tension were found for the stiff cells $(r=0.73$, slope $=$ $\left.2.5 \pm 0.3 \mathrm{nN} / \mu \mathrm{m}^{3}\right)$ and compliant cells $(r=0.75$, slope $=$ $1.0 \pm 0.1 \mathrm{nN} / \mu \mathrm{m}^{3}$ ) separately. (b) Active tension is plotted $v$ resting tension for all cells $(n=43)$. In this case, combined or separated correlations gave the same values $(r=$ 0.8 ). The correlations for two groups of data were not significantly different from that of combined data.

while no correlations at all were found when plotting active tension $v$ systolic SL (not shown). However, when active tension is plotted against resting tension, combining or separating the data gave the same results: the populations are indistinguishable [Fig. 5(b)]. This result clearly indicates that resting tension plays a predominant role in the modulation of active tension by stretch.

\section{Discussion}

In this study, we observed two important things: first, there are two kinds of cell which can be distinguished on the basis of their stiffness; second, putting a strain on compliant cells induced an increase in resting tension, diastolic SL and active tension-surprisingly and interestingly, in stiff cells, we observed that it may induce an increase in active tension without a measurable increase in SL.

Concerning the two populations of cells, we can argue that they are physiological and not artefacts: both kinds of cell were observed in the same cell isolation; the resting calcium and the slack SL are also identical. Concerning the calcium, it is known that the absolute quantification is difficult. These difficulties were also strengthened by the low stimulation frequency $(0.25 \mathrm{~Hz})$ inducing a lower resting calcium level which was more difficult to measure. This is the reason why we also measured slack SL. This parameter is very sensitive to changes in intracellular calcium, $\mathrm{pH}$, ATP, etc. occurring during isolation procedures. Thus, it is a very sensitive parameter to the physiological integrity of the cells. When we observed the distribution of both kinds of cell among the ventricles, we observed that right and left ventricles are constituted of $60 \%$ stiff cells and $40 \%$ compliant cells. The same proportions were broadly observed in the apex and the base of the ventricle. In the endocardium, we found mainly stiff cells $(80 \%)$ while the epicardium is the only part where we found mainly compliant cells $(60 \%)$. However, it must be underlined that the epicardium is very thin, which made it very difficult to study. In our conditions, we probably studied a mixture of cells which contained more epicardial cells than in the whole ventricle, but not exclusively. If so, then there is a tendency for compliant cells to be localized in the epicardium. In fact, it is likely that from the endocardium to epicardium there is a progressive decrease of the ratio stiff/compliant cells. During blood filling, the endocardium is less stretched than is the epicardium (MacKenna et al., 1996). Thus, it is not surprising that endocardial cells are mainly stiff and epicardial cells are mainly compliant to follow changes in ventricular shape during diastolic filling. To support our hypothesis, Kang et al. (1996) found that, in bovine hearts, the endocardium is stiffer than is the epicardium in the low strain range. Even if in their case the collagen may play an important role, the difference of stiffness in the heart may have a partial intracellular origin. It must be noted that two such populations have not been found in previous studies on cell stiffness. Some hypothesis may be proposed: (1) species differences. The majority of studies have been performed on rat cells while we worked on guinea pig cells. (2) Cell preparation differences. Studies on cell stiffness have been mainly performed on skinned cells. It is possible that the treatment to skin the cells changes the elastic properties of these cells. 
To explain the difference in stiffness between the two populations of cells, at least two main hypotheses may be proposed: (1) differences in the constitution or proportion of intracellular proteins involved in the resting tension. Indeed, it is now established that titin, a giant protein link between $\mathrm{Z}$ and $\mathrm{M}$ lines of the sarcomeres, is mainly responsible for the high resting tension observed in cardiac preparations (Granzier and Irving, 1995). We can predict that different isoforms of this protein exist. (2) It is established that weak cross-bridges exist at rest (Sollott et al., 1996). Some differences in the number of weak cross-bridges may be present at rest.

Concerning the active properties, there is evidence that cell length may modulate active force in cardiac cells and in skeletal muscle by changing the interfilament spacing (Cecchi and Bagni, 1994; McDonald and Moss, 1995; Wang and Fuchs, 1995; Fuchs and Wang, 1996). Our experimental results cannot be explained on this basis, since the height of the cells did not change very much after stretch because cell length did not. Something else is needed to explain our observations. The auxotonic conditions cannot explain the inotropism of stretch when diastolic SL did not change. Whether cells are in auxotonic or isometric conditions, if diastolic SL and calcium transient are unchanged, the peak of active tension cannot change since it is the lengthening of diastolic SL which is responsible for the inotropism. Our results can be accounted for if resting tension is implied in the modulation of active tension, since, presumably, it is the only measured parameter which changed. In particular, the absence of changes of SL in some stiff cells excludes it as the determinant factor in the relationship between resting and active tension. Indeed, we found that when plotting active tension $v$ passive tension, the two cell groups could not be distinguished. The auxotonic conditions render the quantification of the relation between force and SL impossible.

To explain the relationship between active and passive tension, we can work on the two hypotheses we proposed above on the origin of the difference of stiffness between the two groups of cells:

(1) Titin, the protein mainly involved in the resting tension, may interact with thin filaments. This interaction may modulate the velocity of actin sliding on myosin in vitro (Li et al., 1995; Kellermayer and Granzier, 1996) and in turn contraction. Titin may be the link between the importance of resting tension and changes in $\mathrm{TnC}$ affinity for $\mathrm{Ca}^{2+}$. Since titin is different in skeletal and cardiac muscle, this may explain why the affinity to $\mathrm{Ca}^{2+}$ of cardiac $\mathrm{TnC}$ varies with length in cardiac muscle (Babu et al., 1988) while it does not vary in skeletal muscle (Moss et al., 1991).

(2) It is known that the force developed during a twitch is modulated by the cross-bridge interactions and indicates a co-operativity in the cross-bridge formation. If we assume that more weak crossbridges are present in stiff cells and are responsible for the difference in stiffness, we can imagine that the force applied to these bridges may increase the co-operativity and consequently the force developed during a twitch. Our preliminary experiments using 2,3-Butanedione monoxime, an actin-myosin interaction inhibitor, seem to indicate that resting tension of stiff cells does not involve weak cross-bridges.

In conclusion, in this study we confirm the presence of two populations of cells in the guinea-pig ventricles. Stiff cells seem to be mainly localized in the endocardium and compliant cells in the epicardium. We show that stretching intact isolated cardiac cells induces an increase in active force. Even if a relationship exists between SL (and thus interfilament spacing) and active force, it seems that the primary effect of stretch is to increase resting tension which in turn modulates this positive inotropism. This is clear in experiments on stiff cells where stretch is able to increase the force during a twitch without measurable diastolic sarcomere lengthening.

\section{Acknowledgements}

We are grateful to Dr Ian Findlay for very helpful criticisms on the manuscript. We thank Peter Kohl for helpful technical discussions about the carbon fibre technique. We are indebted to Peter Kohl, Tony Spindler and Denis Noble for the generous gift of the rotatable experimental chamber. We thank Maryse Pingaud for technical assistance, Gilles Pinal for building some electronic devices and Chantal Boisseau for secretarial assistance. This work was supported by le Conseil Régional du Centre, the Génie Biologique et Médical pôle Grand Ouest, le Ministère de l'Enseignement Supérieur et de la Recherche and La Fondation pour la Recherche Médicale.

\section{References}

Allen DG, Kentish JC, 1988. Calcium concentration in the myoplasm of skinned ferret ventricular muscle 
following changes in muscle length. J Physiol 407: 489-503.

Babu A, Sonnenblick EH, Gulati J, 1988. Molecular basis of the influence of muscle length on myocardial performance. Science 240: 74-76.

Bers DM, Bridge JH, SPITZER KW, 1989. Intracellular $\mathrm{Ca}^{2+}$ transients during rapid cooling contractures in guinea-pig ventricular myocytes. J Physiol 17: 537553.

CeCCHi G, BAgni MA, 1994. Myofilament lattice spacing affects tension in striated muscle. News Physiol Sci 9: 3-7.

De Beer EL, Grundeman RL, Wilhelm AJ, van Den Berg C, Caljouw CJ, Klepper D, Schiereck P, 1988. Effect of sarcomere length and filament lattice spacing on force development in skinned cardiac and skeletal muscle preparations from the rabbit. Bas Res Cardiol 83: 410-423.

FAвіAто A, 1981. Myoplasmic free calcium concentration reached during the twitch of an intact isolated cardiac cell and during calcium-induced release of calcium from the sarcoplasmic reticulum of a skinned cardiac cell from the adult rat or rabbit ventricle. J Gen Physiol 78: 457-497.

Fuchs F, WANG Y-P, 1996. Sarcomere length versus interfilament spacing as determinants of cardiac myofilament $\mathrm{Ca}^{2+}$ sensitivity and $\mathrm{Ca}^{2+}$ binding. J Mol Cell Cardiol 28: 1375-1383.

Gannier F, Jacouemond V, Bernango J-C, Garnier D, 1993. Measurement of sarcomere dynamics simultaneously with auxotonic force in isolated cardiac cells. IEEE 40: 1226-1232.

Gannier F, White E, Lacampagne A, Garnier D, Le GUENNEC J-Y, 1994. Streptomycin reverses a large stretch-induced increase in $\left[\mathrm{Ca}^{2+}\right]_{\mathrm{i}}$ in isolated guineapig ventricular myocytes. Cardiovasc Res 28: 11931198.

Gannier F, White E, Garnier D, Le Guennec J-Y, 1996. A possible mechanism for large stretch-induced increases in $\left[\mathrm{Ca}^{2+}\right]_{i}$ in isolated guinea-pig ventricular myocytes. Cardiovasc Res 32: 158-167.

GrANZIER HL, Irving TC, 1995. Passive tension in cardiac muscle: contributions of collagen, titin, microtubules, and intermediate filaments. Biophys J 68: 1027-1044.

Hibberd MG, Jewell BR, 1982. Calcium- and lengthdependent force production in rat ventricular muscle. J Physiol 329: 527-540.

Hofmann PA, Fuchs F, 1987. Effect of length and crossbridge attachment on calcium binding to cardiac troponin C. Am J Physiol 253: C90-C96.

Kang T, Humphrey JD, Yin FCP, 1996. Comparison of biaxial mechanical properties of excised endocardium and epicardium. Am J Physiol 270: H2169-H2176.

Kellermayer MS, Granzier HL, 1996. Calcium-dependent inhibition of in vitro thin-filament motility by native titin. FEBS Lett 380: 281-286.

Kohl P, Spindler AJ, Le Guennec J-Y, 1994. A remotecontrolled 330 deg rotatable perfusion chamber for isolated cell investigations (Abstract). J Physiol 477 (Suppl. P): 16P.

Le Guennec J-Y, Peineau N, Argibay JA, Mongo K, GARNIER D, 1990. A new method of attachment of isolated mammalian ventricular myocytes for tension recording: length dependence of passive and active tension. J Mol Cell Cardiol 22: 1083-1093.

Li Q, Jin J-P, Granzier HL, 1995. The effect of genetically expressed cardiac titin fragments on in vitro actin motility. Biophys J 69: 1508-1518.

MacKenna DA, Omens JH, Covell JW, 1996. Left ventricular perimysial collagen fibers uncoil rather than stretch during diastolic filling. Bas Res Cardiol 91: 111-122.

McDonald KS, Moss RL, 1995. Osmotic compression of single cardiac myocytes eliminates the reduction in $\mathrm{Ca}^{2+}$ sensitivity of tension at short sarcomere length. Circ Res 77: 199-205.

Moss RL, Nwoye LO, Greaser ML, 1991. Substitution of cardiac troponin $\mathrm{C}$ into rabbit muscle does not alter the length dependence of $\mathrm{Ca}^{2+}$ sensitivity of tension. $J$ Physiol 440: 273-289.

O'NeILl SC, Donoso P, EISNER DA, 1990. The role of $\left[\mathrm{Ca}^{2+}\right]_{\mathrm{i}}$ and $\left[\mathrm{Ca}^{2+}\right]$ sensitization in the caffeine contracture of rat myocytes: measurement of $\left[\mathrm{Ca}^{2+}\right]_{\mathrm{i}}$ and $[\text { caffeine }]_{\mathrm{i}}$ J Physiol (Lond) 425: 55-70.

Sollott SJ, Ziman BD, Warshaw DM, Spurgeon HA, LAKATTA EG, 1996. Actomyosin interaction modulates resting length of unstimulated cardiac ventricular cells. Am J Physiol 271: H896-H905.

WANG Y-P, FuCHS F, 1995. Osmotic compression of skinned cardiac and skeletal muscle bundles: effects on force generation, $\mathrm{Ca}^{2+}$ sensitivity and $\mathrm{Ca}^{2+}$ binding. J Mol Cell Cardiol 27: 1235-1244.

White E, Le Guennec J-Y, Nigretto JM, Gannier F, Argibay JA, Garnier D, 1993. The effects of increasing cell length on auxotonic contractions, membrane potential and intracellular calcium transients in single guinea-pig ventricular myocytes. Exp Physiol 78: 6578.

White E, BoyetT MR, Orchard CH, 1995. The effects of mechanical loading and changes of length on single guinea pig ventricular myocytes. J Physiol 482: 93108. 